\title{
Control of cell number by Drosophila FOXO: downstream and feedback regulation of the insulin receptor pathway
}

\author{
Oscar Puig, Michael T. Marr, M. Laure Ruhf, ${ }^{1}$ and Robert Tjian ${ }^{2}$ \\ Howard Hughes Medical Institute and Department of Molecular and Cell Biology, University of California, Berkeley, \\ California 94720, USA
}

\begin{abstract}
The Drosophila insulin receptor (dInR) regulates cell growth and proliferation through the dPI3K/dAkt pathway, which is conserved in metazoan organisms. Here we report the identification and functional characterization of the Drosophila forkhead-related transcription factor dFOXO, a key component of the insulin signaling cascade. dFOXO is phosphorylated by dAkt upon insulin treatment, leading to cytoplasmic retention and inhibition of its transcriptional activity. Mutant dFOXO lacking dAkt phosphorylation sites no longer responds to insulin inhibition, remains in the nucleus, and is constitutively active. dFOXO activation in $\mathbf{S 2}$ cells induces growth arrest and activates two key players of the dInR/dPI3K/dAkt pathway: the translational regulator d4EBP and the dInR itself. Induction of d4EBP likely leads to growth inhibition by dFOXO, whereas activation of dInR provides a novel transcriptionally induced feedback control mechanism. Targeted expression of dFOXO in fly tissues regulates organ size by specifying cell number with no effect on cell size. Our results establish dFOXO as a key transcriptional regulator of the insulin pathway that modulates growth and proliferation.
\end{abstract}

[Keywords: Insulin signaling; transcription factor; FOXO; Drosophila; growth; feedback]

Received March 27, 2003; revised version accepted June 19, 2003.

During the development of multicellular organisms, growth is tightly regulated by controlling cell number and cell size so that each organ reaches its appropriate dimensions in relation to the size of the organism. Many studies indicate that growth and proliferation are coordinated but distinct processes and that cells progress through the cell cycle only when sufficient mass, size, and macromolecular biosynthesis have been reached. (Hartwell et al. 1974; Johnston et al. 1977; Weigmann et al. 1997). Organism growth is controlled by coordinating both cell cycle progression and survival, which is modulated by nutrient availability, growth factors, and temperature. Growth factors can stimulate cell division and survival by activating the insulin receptor, which in turn acts through two main signal transduction cascades: the Ras/MAP kinase (Lee and McCubrey 2002) and the PI3K/ Akt kinase pathways (Cantley 2002). Insulin-mediated activation of PI3K increases production of 3'-phosphorylated phosphoinositide lipids $\left(\mathrm{PIP}_{3}\right)$ that serve as second

${ }^{1}$ Present address: Friedrich Miescher Institute, Maulbeerstrasse 66, Basel 4058, Switzerland.

${ }^{2}$ Corresponding author.

E-MAIL jmlim@uclink4.berkeley.edu; FAX (510) 643-9547.

Article published online ahead of print. Article and publication date are at http://www.genesdev.org/cgi/doi/10.1101/gad.1098703. messengers to recruit Akt to the plasma membrane (Datta et al. 1999). Once properly localized in the membrane, Akt becomes activated by phosphorylation and in turn phosphorylates a number of downstream targets that ultimately regulate cell growth. For example, Akt stimulates protein synthesis through activation of the target of rapamycin (TOR) kinase, which subsequently phosphorylates and inactivates the translational repressor eukaryotic initiation factor 4E-binding protein (4EBP; Gingras et al. 2001).

In addition to modulating translation, Akt regulates transcription through the forkhead-related FOXO family of transcription factors FOXO1, FOXO3a, and FOXO4 (Burgering and Kops 2002) by phosphorylating these proteins at three conserved serine/threonine residues. This leads to retention of FOXO transcription factors in the cytoplasm, thereby down-regulating RNA synthesis of specific target genes (Burgering and Kops 2002) that affect cell cycle progression (Kops et al. 1999; Alvarez et al. 2001) and apoptosis (Brunet et al. 1999; Dijkers et al. 2000) and modulate metabolic genes (Ayala et al. 1999; Durham et al. 1999; Guo et al. 1999; Hall et al. 2000; Nasrin et al. 2000; Schmoll et al. 2000; Nakae et al. 2001; Nadal et al. 2002). Thus, FOXO transcription factors play a critical role in regulating cell growth and survival. 
Recent genetic studies in Drosophila and Caenorhabditis elegans show that the InR/PI3K/Akt signaling pathway is largely conserved in metazoans (Fig. 1A). In invertebrates, this pathway apparently plays an essential role in regulating life span as well as body, organ, and cell size (Finch and Ruvkun 2001). C. elegans can enter the dauer state when food is limited; when conditions improve, growth is stimulated by activating the InR/PI3K/ Akt signaling pathway. Worms with mutations in this pathway are small (Hekimi et al. 1998), their organs have fewer cells, and they live longer. Interestingly, mutations in the transcription factor DAF-16 suppress this phenotype (Lin et al. 1997; Ogg et al. 1997), suggesting that this key transcription factor is negatively regulated by the InR/PI3K/Akt pathway (Burgering and Kops 2002). In Drosophila, the dInR/dPI3K/dAkt pathway is also thought to regulate body size and life span (Fig. 1A). Flies with heteroallelic combinations of $d \operatorname{In} R$ mutations are reduced in size because of fewer and smaller cells (Fernandez et al. 1995; Chen et al. 1996; Brogiolo et al. 2001). Mutations in other components of the dInR/dPI3K/dAkt pathway produce similar phenotypes (Stocker and Hafen 2000; Johnston and Gallant 2002; Kozma and Thomas 2002). Although the identity and number of specific gene targets of the insulin signaling pathway in Drosophila remain unclear, one important downstream effector of insulin signaling appears to be the translational inhibitor d4EBP (Miron et al. 2001).

Despite the importance of the dInR/dPI3K/dAkt pathway in regulating cell growth and proliferation in Drosophila, little is known about how signaling is controlled downstream of dAkt (Fig. 1A). In C. elegans and mammals, a critical member of this pathway downstream of Akt is the transcription factor DAF-16/FOXO, which counteracts insulin signaling. However, the Drosophila equivalent of DAF-16/FOXO has thus far not been described. In addition, the mechanisms, if any, that are used to provide feedback regulation of the InR pathway are unknown. Here, we describe the cloning and characterization of the Drosophila homolog of DAF-16/FOXO. We have investigated whether dFOXO is regulated by the dInR/dPI3K/dAkt pathway, searched for downstream target genes, and analyzed the biological role of dFOXO in Drosophila. Our results suggest that dFOXO is a key transcriptional regulator that controls both downstream target genes responsible for growth as well as upstream feedback targets in the insulin signaling pathway.

\section{Results}

\section{Identification and cloning of dfoxo}

Homology searches using FOXO4 or its DNA-binding domain revealed the presence of only one Drosophila gene with high similarity to FOXO transcription factors. We sequenced several cDNA clones, and the longest open reading frame encodes a protein of 613 amino acids with a calculated molecular mass of $67,412.12 \mathrm{D}$. We have designated this protein as dFOXO. The $d$ foxo gene contains 11 exons spanning $40 \mathrm{~kb}$. The DNA-binding domain is located in the $\mathrm{N}$-terminal region and has $45 \%$ identity with human FOXO4 (84\% identity in the region that spans the three $\alpha$-helices constituting the forkhead core domain; Fig. 1B). The homology with two other members of the FOXO family, FOXO1 and FOXO3a, is also significant in the DNA-binding domain. All four proteins share a characteristic five-amino-acid insertion (SNSSA) between $\alpha$-helices 2 and 3 of the forkhead domain, which differentiates this subset from other forkhead-related family members (Fig. 1C). Importantly, the three residues phosphorylated by Akt in FOXO4 are conserved in dFOXO: T28, S193, and S258 in FOXO4 correspond to T44, S190, and S259 in dFOXO (Fig. 1B, boldface residues). The amino acids that define the motif recognized by Akt (RXRXXS/T) are also conserved (Fig. $1 \mathrm{~B}$, boxed residues). dFOXO has a C-terminal region with a high Ser and Gln content $11.7 \%$ and $13.4 \%$, respectively), commonly found in transcription activation domains.

\section{dFOXO is phosphorylated upon insulin treatment in $S 2$ cells}

Rabbit polyclonal antibodies raised against either the $\mathrm{N}$ or C-terminal region of dFOXO recognize a single major polypeptide in Drosophila embryo extracts with an apparent molecular mass of $113 \mathrm{kD}$ as determined by SDSPAGE (Fig. 1D). To confirm that this protein corresponds to $\mathrm{dFOXO}$, we expressed a V5-epitope-tagged version of dFOXO under control of the metallothionein promoter. When this $\mathrm{Cu}^{2+}$-inducible construct was transfected into Schneider line 2 (S2) cells, both $\mathrm{N}$ - and C-terminal antibodies as well as the V5 antibody specifically recognized a major polypeptide with the same mobility $(113 \mathrm{kD})$ that was found in embryo extracts (data not shown). We have therefore designated this $113-\mathrm{kD}$ protein as dFOXO. Western blot analysis confirmed that untransfected S2 cells express endogenous dFOXO at a level similar to that found in embryo extracts (data not shown).

If the $\mathrm{dFOXO}$ protein we have identified is a bona fide ortholog of mammalian FOXO, insulin should regulate its activity by phosphorylation via a cascade involving Akt (Brunet et al. 1999; Kops et al. 1999). Also, phosphorylation of the three specific serine/threonine residues should sequester this transcription factor in the cytoplasm. To test these properties, S2 cells were grown with or without insulin, and endogenous $\mathrm{dFOXO}$ was detected by Western blot analysis. A single band migrating with molecular mass $113 \mathrm{kD}$ was recognized by both $\mathrm{N}$ - and C-terminal dFOXO antibodies in the untreated samples (Fig. 1E, lane 1; data not shown). In contrast, the insulin-treated sample revealed the presence of two bands, one migrating with the mobility of $113 \mathrm{kD}$ and a second band with slower mobility (Fig. 1E, lane 2, marked with an asterisk). A similar insulin-induced shift was obtained with transfected dFOXO-V5 expressed in S2 cells and detected with a V5 antibody (Fig. 1E, cf. lanes 4 and 3). These results suggested that the slowermigrating band may correspond to a phosphorylated form of dFOXO. 
Puig et al.

Figure 1. (A) The insulin receptor signaling pathway is conserved in mammals, $C$. elegans, and Drosophila. (B) Identification of a Drosophila homolog of FOXO/DAF16. Sequence alignment showing the high degree of conservation displayed in the DNA-binding domains of FOXO4 and dFOXO. The three conserved Akt phosphorylation motifs are boxed, and the amino acids that can be phosphorylated are in boldface. Asterisks mark identical amino acids; colons mark conserved amino acid changes; dots indicate weakly conserved changes. (C) FOXO family members have a 5-amino-acid insertion between helices 2 and 3 in the DNA-binding domain, which is lacking in the rest of forkhead-related proteins. $(D)$ Antibodies raised against recombinant $\mathrm{C}$ - and $\mathrm{N}$-terminal regions of $\mathrm{dFOXO}$ recognize a band with similar mobility in Drosophila S2 cell extracts. A representation of dFOXO indicating the fragments used for antibody production is shown below. (E) Insulin treatment produces a slower-mobility form of dFOXO (marked with an asterisk) that is detected with endogenous (lanes 1,2) or overexpressed (lanes 3,4) dFOXO. $(F)$ Overexpressed dFOXO is phosphorylated upon insulin treatment of S2 cells (lane 2). Pretreatment of samples with LY294002 before insulin treatment reduces the amount of dFOXO that is phosphorylated (lane 3). dFOXOA3 is not phosphorylated upon insulin treatment (lanes 4-6). The lower panel shows the same samples after phosphatase treatment. A scheme representing wild-type and mutant dFOXO is shown below.

\section{A}

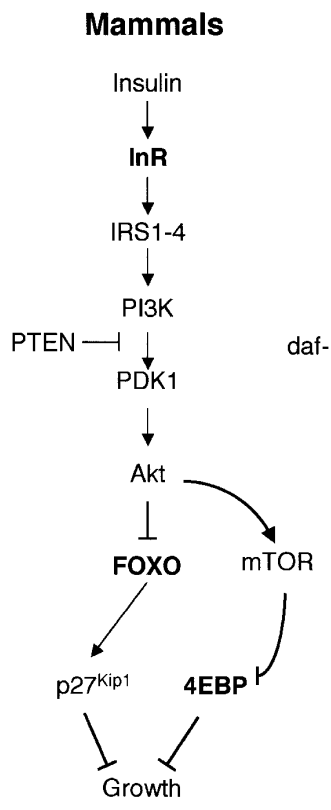

C.elegans

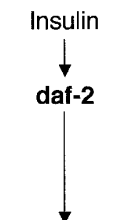

af-18
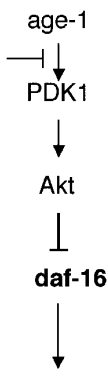

Life-span
Drosophila

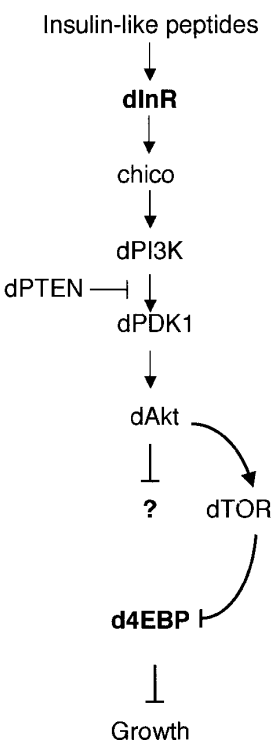

B

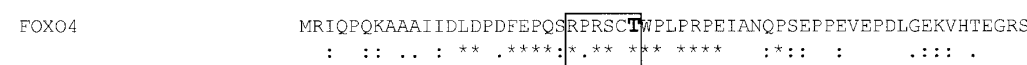
AEOXO MMDGYAQEWPRLTHTDNGLAMDQLGGDLPLDVGFEPQTRARSNMNPCPRPENFVEPTDELDSTKA.SNQQLAP---FOXO4 EPILLPSRLSEPAGGPQPGILGAVTGRRKGGSRRNAWGNQSYAEEISQAIESAPEKRITLAQIYEWMVRTVPYEKD

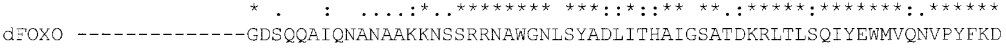
FOXO4 KGDSNSSAGWKNSI RHNISLHSKEIKVHNEATGKSSWWMLNPEGGKSGKAPRRRAASMDSS-SKLLRGRSK---AP dFOXO KGDSNSSAGWKNSIRHNLSLHNREMRVNEGTGKSSWWMLNPEAK-PGKSURRRAASVETSRYEKRRGRAKKRVEA FOXO4 KKKESVLPAPPEGATPTSPVGHEAKWSGSPCSRNREEADMWTTERPRSSSNASSVSTRLSPLRPE------- 273

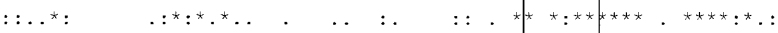

dZOXO LRQAGVVGINDATPSPSSVSEGLDHFPESPLHSGGGELSPDERQRASSNASSCG-RLSPIRAQDLEPDWG 280

C

$\operatorname{hnf3a}$

$\operatorname{hnf} 3 g$

$\mathrm{fkh}$

gin

bf -1

FKH-5

$\operatorname{sip}-2$

FOXO3a

FOXO1

EOXO

D

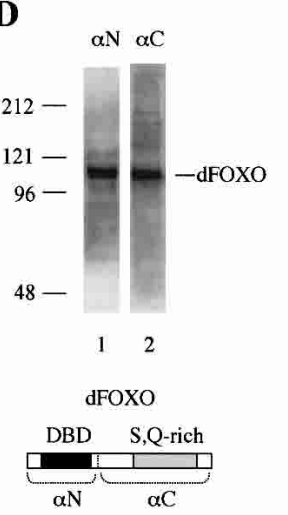

Helix 1

Helix 2

Helix 3

RTONSTRHSTSFNDCFVKVARSPDKP RWONSIRHSLSFNDCEVKVARSPDKE RWQNSIRHSLSFNDCEVKIPRTPDKE GWONSIRHNLSLNKCFVKVPRHYDDP GWQNS I RHNLSLNKCFVKVPRHYDDP
GWONS I RHNLSLNKCFVKVPRHYDDF $\begin{array}{ll}\text { YEKP F SYNALIMMAIRQSPEKRLTINGIYEFIMKNFPYYRENKQ } & \text { GWQNSIRHNLSLNKCFVKVPRHYDDP } \\ \text { DQKPPYSYISLTAMAIQSSPEKMLPISEIYKF IMDREPYYRENTQ } & \text { RWQNSLRHNLSFNDCFIKIPRRPDQP } \\ \text { NEKPPYSYNALIMMAIRQSSEKRLTLNGIYEYIMTNHPYYRDNKQ } & \text { GWQNSIRHNLSLNKCFVKVPRHYDDP }\end{array}$ $\begin{array}{ll}\text { YEKP F SYNALIMMAIRQSPEKRLTINGIYEFIMKNFPYYRENKQ } & \text { GWQNSIRHNLSLNKCFVKVPRHYDDP } \\ \text { DQKPPYSYISLTAMAIQSSPEKMLPISEIYKF IMDREPYYRENTQ } & \text { RWQNSLRHNLSFNDCFIKIPRRPDQP } \\ \text { NEKPPYSYNALIMMAIRQSSEKRLTLNGIYEYIMTNHPYYRDNKQ } & \text { GWQNSIRHNLSLNKCFVKVPRHYDDP }\end{array}$ NAWGNLSYADI I'T RAIESSPDKRLTLSQIYEWMVRCVPY FKDKGDSNSSAGWKNS IRHNLSLHSRFMRVQNEGTGK NAWGNLSYADL I TKA IESSAEKRLTLSQI YEWMVKSVPYEKDKGDSNSSAGWKNS I RHNLSLHSKFI RVQNEGTGK NAWGNQSYAEF ISQA I ESAPEKRLTLAQ IYEWMVRTVPY EKDKGDSNSSAGWKNS I RHNLSL HSKF I KVHNEATGK NAWGNLSYADL I THA IGSATDKRLTLSQI YEWMVQNVPYEKDKGDSNSSAGWKNS IRHNLSL HNRFMRVQNEGTGK

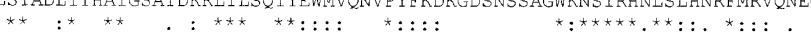


To establish that the slower-migrating form of dFOXO induced by insulin treatment is indeed caused by dAktcatalyzed phosphorylation, we constructed a mutant form of dFOXO in which all three putative dAkt phosphorylation sites (T44, S190, and S259) were mutated to alanine (dFOXOA3). Both wild-type (dFOXO-V5) and mutant (dFOXOA3-V5) proteins were expressed in S2 cells. After transient expression, the cells were subjected to three different treatments in parallel: insulin (Fig. 1F, lanes 2,5); pretreatment with LY294002 (a specific inhibitor of PI3K that counteracts the effects of insulin) followed by insulin treatment (Fig. 1F, lanes 3,6); or no treatment control (Fig. 1F, lanes 1,4). Extracts derived from cells treated with insulin contained the slower-migrating form of wild-type dFOXO when compared with control cells (Fig. 1F, upper panel, cf. lanes 2 and 1). Pretreatment with the PI3K inhibitor LY294002 reduced the amount of the slower-migrating form of dFOXO (Fig. 1F, lane 3). In contrast, no slower-migrating species was observed for the triple alanine mutant (dFOXOA3) when comparing control, insulin-treated, and LY294002 + insulin-treated samples (Fig. 1F, lanes 4-6). To further confirm that the slower-migrating form of dFOXO was caused by phosphorylation, cell extracts were incubated with calf intestinal phosphatase (CIP). Western blot analysis (Fig. 1F, lower panel) showed that the slowermigrating form of dFOXO was quantitatively converted to the $113-\mathrm{kD}$ form after CIP treatment. Together, these results indicate that $\mathrm{dFOXO}$ is phosphorylated by insulin treatment and that this phosphorylation depends on the presence of the dAkt consensus residues T44, S190, and S259.

\section{Insulin induces cytoplasmic localization of dFOXO}

To test how dFOXO subcellular localization is affected by insulin-mediated phosphorylation, $\mathrm{S} 2$ cells expressing either wild-type dFOXO or mutant dFOXOA3 were incubated for $48 \mathrm{~h}$ in the absence of serum. Then insulin was added, and localization of transfected dFOXO was determined by confocal microscopy after staining with the V5 antibody. When S2 cells are incubated in the absence of serum and insulin, both dFOXO and dFOXOA3 are found predominantly in the nucleus (Fig. 2A,C). After insulin treatment, dFOXO is localized in the cytoplasm (Fig. 2B). In contrast, mutant dFOXOA3 remains nuclear even after insulin treatment (Fig. 2D). This result is consistent with the idea that subcellular localization of $\mathrm{dFOXO}$ is regulated by insulin.

\section{dAkt phosphorylates dFOXO and inhibits its activity}

We next asked whether dFOXO phosphorylation is regulated through the dPI3K/dAkt pathway. We used a constitutively active form of dAkt in which a myristoylation signal has been fused to the $\mathrm{N}$ terminus of dAkt (Verdu et al. 1999). Myr-dAkt tagged with V5 epitope was cotransfected in S2 cells grown in the absence of serum and insulin with either dFOXO or dFOXOA3, and the phosphorylation state of both proteins was analyzed by Western blot analysis. In the absence of dAkt, both $\mathrm{dFOXO}$ and dFOXOA3 remain unphosphorylated (Fig. 2E, upper panel, lanes 1,2). When Myr-dAkt was present in the cells, dFOXO but not dFOXOA3 becomes phosphorylated even in the absence of insulin (Fig. 2E, upper panel, lanes 4,5). This result indicates that MyrdAkt can phosphorylate dFOXO in S2 cells. To assess the effect of dFOXO phosphorylation by Myr-dAkt, we made use of a reporter construct containing four tandem FOXO4-binding sites upstream of the alcohol dehydrogenase distal core promoter driving the luciferase gene (pGL4xFRE). In the absence of Myr-dAkt, cells cotransfected with wild-type or mutant dFOXO constructs incubated without serum displayed comparable luciferase activity (Fig. 2E, lower panel, lanes 1,2). In contrast, when Myr-dAkt is present, cells cotransfected with wildtype dFOXO displayed luciferase activity that was reduced by more than $65 \%$ (Fig. 2E, lower panel, lane 4), whereas activity of the mutant dFOXOA3 remained essentially unchanged (Fig. 2E, lower panel, cf. lanes 2 and 5).

The results presented above suggest that insulin induces dFOXO phosphorylation through dAkt, which leads to cytoplasmic localization and transcriptional inactivation of dFOXO. To further confirm that insulin inhibits dFOXO activity through dAkt, we performed RNAi experiments. S2 cells transfected with either dFOXO or dFOXOA3 and cotransfected with the luciferase reporter pGL4xFRE were grown in the presence of insulin and treated with dsRNA directed against dAkt. As a control, dsRNA against lactose repressor (lacI) was used. As expected, dFOXO activity is not inhibited by insulin when cells are depleted of dAkt by dsRNA treatment, but it is inhibited in the lacI control (Fig. 2F, cf. lanes 2 and 4). These results confirm that dAkt mediates insulin inhibition of dFOXO.

\section{Expression of constitutively active dFOXO arrests cell growth}

Studies with several components of the dInR/dPI3K/ dAkt pathway have shown that insulin promotes growth and proliferation by activating dPI3K and dAkt (Kozma and Thomas 2002). We have shown that dFOXO activity is inhibited by dAkt upon insulin treatment (Fig. 2E). We therefore wanted to know whether induction of dFOXO would inhibit growth in S2 cells. To do so, we cultured S2 cells stably transfected with either dFOXO or mutant dFOXOA3 in the presence of serum and insulin for $48 \mathrm{~h}$. Then exogenous $\mathrm{dFOXO}$ and $\mathrm{dFOXOA} 3$ expression was induced with $\mathrm{CuSO}_{4}$ for a period of $8 \mathrm{~h}$. Subsequently, $\mathrm{Cu}^{2+}$ was removed, and cells were then allowed to divide for $1 \mathrm{wk}$ with samples taken every $12 \mathrm{~h}$ to measure cell numbers. Cells stably transfected with the wild-type protein proliferated at the same rate irrespective of dFOXO induction (Fig. 3A, , O). In contrast, cells stably transfected with the mutant protein, dFOXOA3, displayed a significantly slower growth rate when compared with the same cells grown without dFOXOA3 induction 
Puig et al.
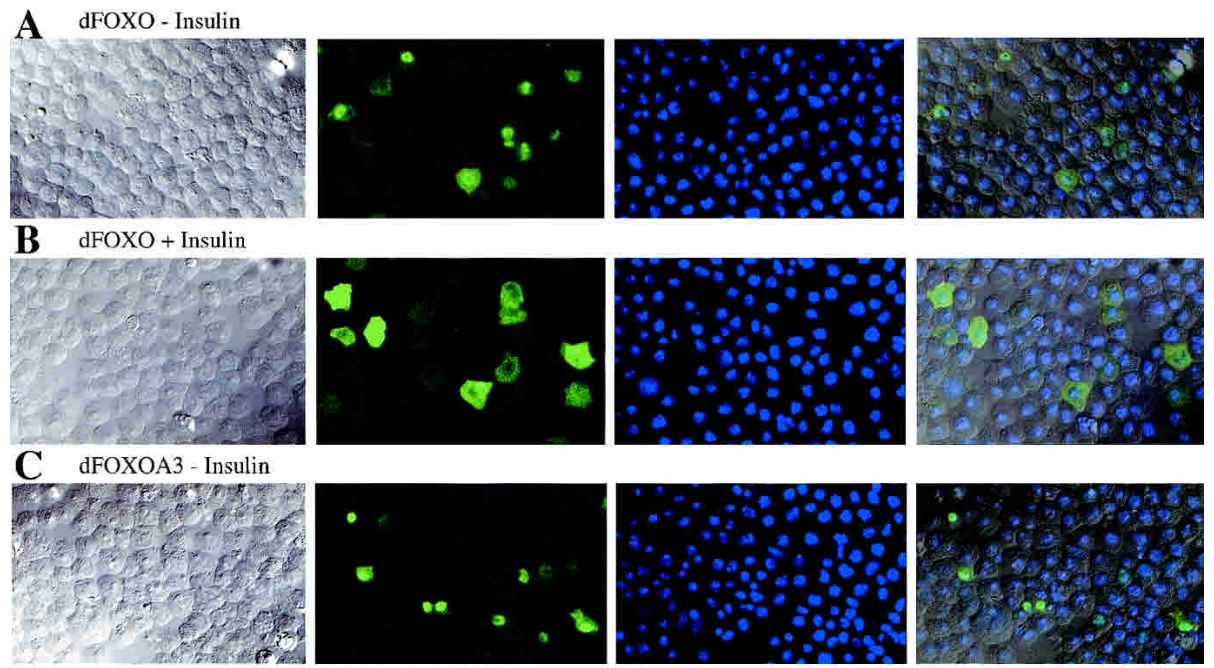

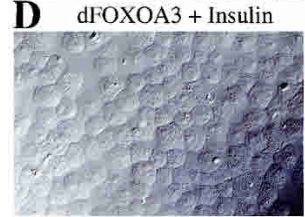

DIC

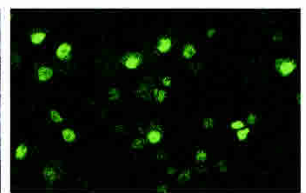

FITC

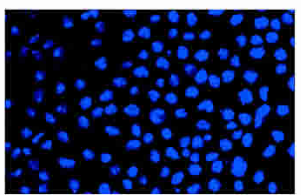

DAPI

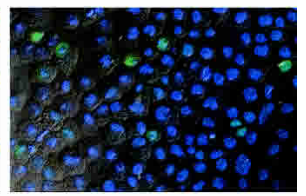

Merge

$\mathbf{E}$
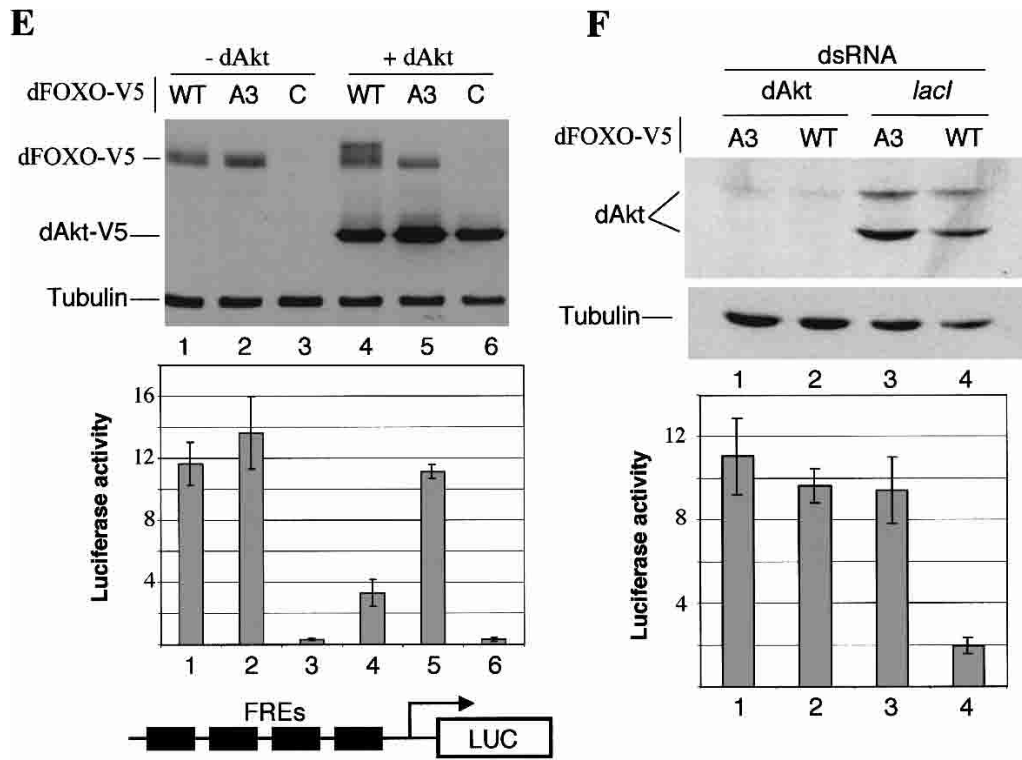

Figure 2. $(A-D)$ Insulin regulates subcellular localization of dFOXO. S2 cells overexpressing dFOXO or dFOXOA3 were grown in the absence $(A, C)$ or presence $(B, D)$ of insulin. $(E)$ Akt phosphorylates and inhibits dFOXO activity. (Top) S2 cells grown in the absence of serum/insulin were transfected with dFOXO [wild-type (WT) lanes 1,4], dFOXOA3 (A3, lanes 2,5), or with empty vector (C, lanes 3,6). Myr-dAkt-V5 was cotransfected in lanes 4-6. (Bottom) Luciferase assays performed with the samples from above and measured with a reporter containing four FOXO4 recognition elements. $(F)$ Insulin inhibits dFOXO through dAkt. Cells were transfected with dFOXO (lanes 2,4) or dFOXOA3 (lanes 1,3) and dsRNA against dAkt (lanes 1,2) or lacI (lanes 3,4) was added. (Bottom) Luciferase activity was measured with the same reporter as in $E$.

(Fig. 3A, $\mathbf{\square}, \square$ ). Because insulin was present throughout these experiments (inactivating dFOXO but not dFOXOA3), our findings suggest that the constitutively active $\mathrm{dFOXOA} 3$ can induce cell arrest. Importantly, cells expressing dFOXOA3 arrest growth during the first $44 \mathrm{~h}$ after induction when dFOXOA3 is present. After 44 $\mathrm{h}$, when dFOXOA3 has apparently been turned over (Fig. 3B, lower panel, 68-164 h), cells recover and start dividing normally again (Fig. 3A, $\square, 68-164 \mathrm{~h}$ ). FACS analysis of samples taken during the different time points indicates that S2 cells arrest their growth at G2/M (Fig. 3C; data not shown). These results indicate that activation of 
A

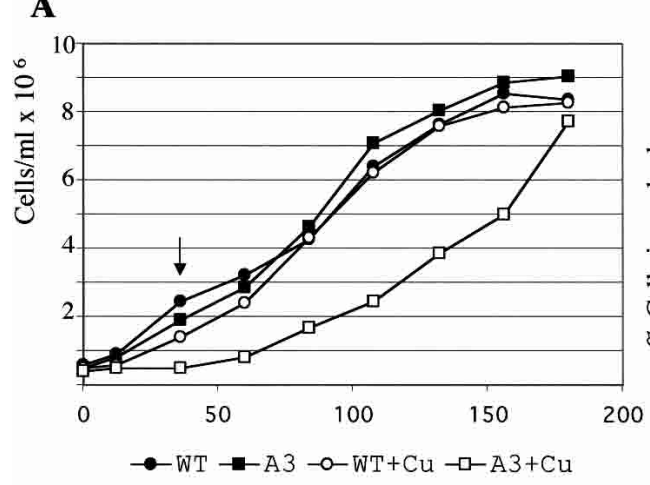

C

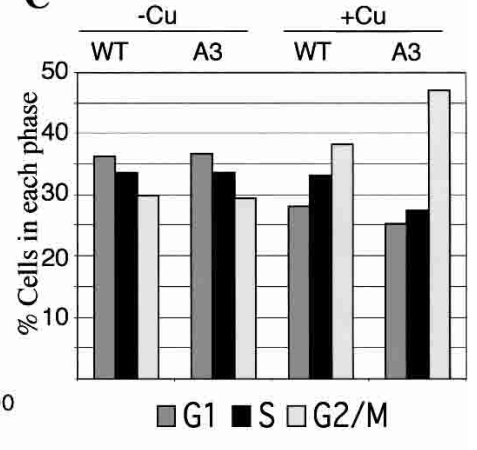

B

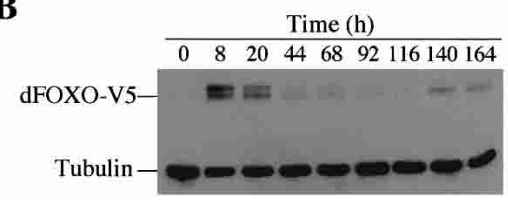

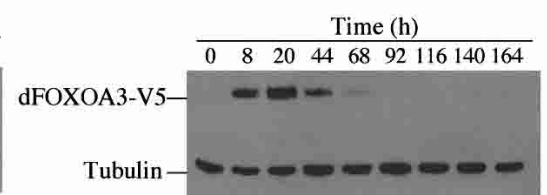

Figure 3. dFOXO arrests cell growth. (A) S2 cells stably transfected with either wild-type $\operatorname{dFOXO}(\bullet, O)$ or A3 mutant $(\mathbf{\square}, \square)$ were grown in the presence of insulin. To induce dFOXO expression, an 8-h pulse of $\mathrm{Cu}^{2+}$ was performed $(\bigcirc, \square)$. Only cells expressing dFOXOA3 stop growing during the first $44 \mathrm{~h}$. $(B)$ Western blot of cell extracts obtained from cells induced with $\mathrm{Cu}^{2+}$ in $A$. $(C)$ Frequencies for G1, S, or G2/M as assayed by FACS for cells after $36 \mathrm{~h}$ of $\mathrm{Cu}^{2+}$ addition (arrow in $A$ ).
dFOXO can induce cell cycle arrest and this effect is mitigated by insulin.

\section{dFOXO activates $d \operatorname{InR}$ and $d 4 E B P$ transcription}

The results presented above suggest that $\mathrm{dFOXO}$ regulates cell cycle arrest possibly by transcriptionally activating genes implicated in cell division or in cell growth. As an initial attempt to identify target genes of dFOXO, DNA microarrays were used to assess gene expression profiles in S2 cells stably transfected with mutant dFOXO and grown in the presence of insulin. Cells expressing wild-type dFOXO or untransfected S2 cells subjected to the same treatment were assayed as controls.

We found that 277 genes were up-regulated in dFOXOA3expressing cells when compared with dFOXO-expressing cells or untransfected S2 cells. Interestingly, two genes that were consistently and specifically up-regulated in these conditions were the dInR gene (13.5-fold) and the d4EBP gene (25-fold; Fig. 4A). Both genes have been implicated in the regulation of cell growth by insulin (Fernandez et al. 1995; Miron et al. 2001). As expected, experimental control genes such as actin or GAPDH remained unchanged under these conditions (Fig. 4A). To confirm that $\mathrm{dInR}$ and $\mathrm{d} 4 \mathrm{EBP}$ are bona fide transcriptional targets of $\mathrm{dFOXO}$, we performed the same experiment described above but in the presence of cycloheximide to inhibit translation. As expected, both dInR and d4EBP continued to be transcriptionally activated (2.5- and 3.1-fold, respectively) by dFOXOA3 but not $\mathrm{dFOXO}$ in the insulin-repressed state. This result suggests that dFOXO, when released from control by the insulin/dAkt cascade, is involved in transcription from the $\mathrm{dInR}$ and d4EBP promoters.

To confirm these microarray results and to independently quantitate the increase in mRNA transcription, we performed RNase protection assays with mRNAs extracted from cells stably transfected with either
dFOXO or dFOXOA3. Indeed, dFOXOA3 stimulated transcription of d4EBP and dInR by 16.3- and 11-fold, respectively. A time-course experiment (Fig. 4B) confirmed that dInR mRNA increased rapidly upon dFOXOA3 expression: $3 \mathrm{~h}$ after $\mathrm{CuSO}_{4}$ addition, there is already an 8-fold increase, reaching 20-fold after $9 \mathrm{~h}$ of $\mathrm{CuSO}_{4}$ induction. Similar results were obtained for d4EBP (data not shown).

To exclude the possibility that treatment with insulin and/or $\mathrm{CuSO}_{4}$ per se causes the effects seen on transcription of dInR and d4EBP, cells stably transfected with $\mathrm{dFOXO}$ or dFOXOA3 were grown in the presence of either insulin or $\mathrm{CuSO}_{4}$, or with both insulin and $\mathrm{CuSO}_{4}$ (Fig. 4C). In the absence of insulin and presence of $\mathrm{CuSO}_{4}$, both dFOXO and dFOXOA3 activate dInR and d4EBP transcription (Fig. 4C, lanes 3,4; data not shown). However, in the presence of insulin and $\mathrm{CuSO}_{4}$, only the constitutively active $\mathrm{dFOXOA} 3$ induced transcription of these two target genes (Fig. 4C, lanes 7,8; data not shown). In the absence of $\mathrm{CuSO}_{4}$, no activation is seen (Fig. 4C, lanes $1,2,5,6)$. These results rule out the possibility that insulin $/ \mathrm{Cu}^{2+}$ treatment by itself activated transcription of these genes. Instead, our experiments suggest that $\mathrm{dFOXO}$ expression specifically activates both dInR and d4EBP transcription, thus unmasking an important feedback control mechanism in this pathway involving dFOXO and dInR.

Having obtained evidence that exogenously transfected dFOXO responds to insulin and regulates both the downstream target gene d4EBP and the feedback control target dInR, we next wanted to know if endogenous dFOXO would also activate transcription of these genes. We used the PI3K inhibitor LY294002 to activate endogenous dFOXO or insulin to deactivate it. S2 cells grown in the absence of serum for $48 \mathrm{~h}$ were treated either with LY294002 or insulin. Total RNA was extracted and RNase protection was performed to detect dInR and d4EBP mRNAs. Both mRNA levels are significantly increased after LY294002 treatment 15.3-fold for dInR and 
Puig et al.

Figure 4. dInR and d4EBP are up-regulated by dFOXO. (A) DNA microarrays detected dInR and d4EBP as putative targets for dFOXO. Actin and GAPDH controls remained unchanged. RNase protection confirmed microarray data. (B) RNase protection shows a rapid induction of $\mathrm{dInR}$ messenger by dFOXOA3. $(C) \mathrm{Cu}^{2+}$ or insulin treatments per se do not induce transcription of dInR. In the absence of insulin, both wild-type and A3 mutant induce transcription of dInR. In the presence of insulin, only A3 mutant up-regulates this mRNA. (D) The PI3K inhibitor LY294002 induces transcription of dInR and d4EBP, suggesting that endogenous $\mathrm{dFOXO}$ is responsible for this effect. For all the panels, the graphic below represents the quantification of data performed on the RNase protection experiment shown above.
$\mathbf{A}$

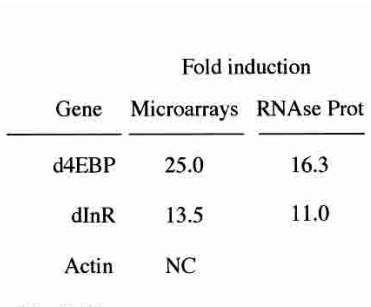

18s rRNA

GAPDH

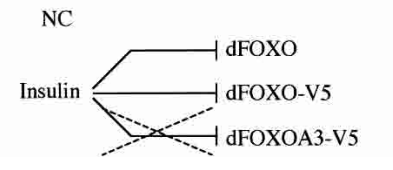

C

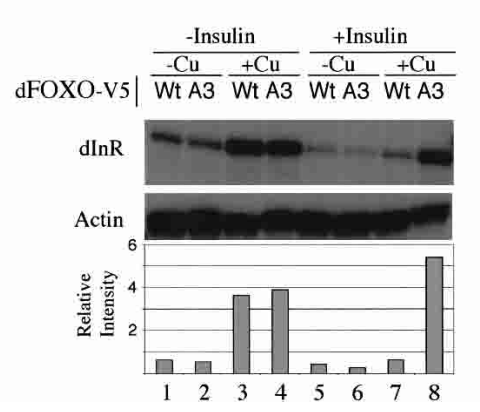

B

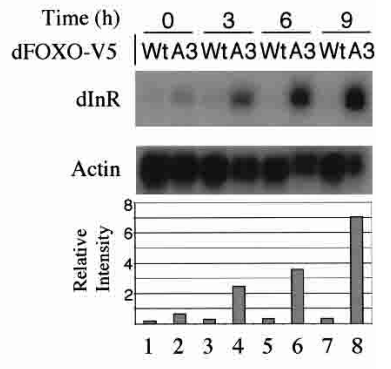

D

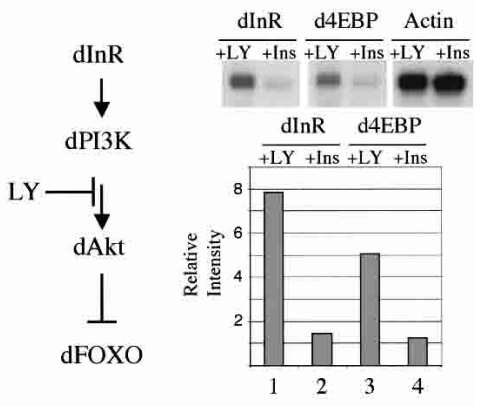

4-fold for d4EBP) when compared with insulin treatment (Fig. 4D). This result provides further evidence indicating that the dPI3K-dAkt pathway regulates $\mathrm{dInR}$ and d4EBP transcription via dFOXO.

\section{dFOXO binds to both the d4EBP and the dInR promoters and activates their transcription}

We next wanted to determine whether dFOXO directly binds to the promoters of d4EBP and dInR. To identify the DNA region recognized by dFOXO in these two promoters, we inserted a 1708-bp fragment of the d4EBP promoter and a 1562-bp fragment of the dInR promoter into a luciferase reporter vector. When transfected into $\mathrm{S} 2$ cells, these fragments responded to dFOXO activation (3-fold for d4EBP, >200-fold for dInR; Fig. 5A, lanes 2,6). A series of deletions lacking upstream sequences still responded to dFOXO activation, albeit more weakly (Fig. $5 \mathrm{~A}$, lanes $3,4,7,8)$, suggesting that $\mathrm{dFOXO}$ can bind the DNA in a region close to the start of transcription $(485$ bp for the d4EBP promoter and $194 \mathrm{bp}$ for the dInR promoter). In contrast, dFOXO completely fails to activate a reporter construct in which upstream activating sequences (UAS) for the transcription factor GAL4 are fused to the luciferase gene (data not shown), confirming that transcription activation is specific for both d4EBP and $\mathrm{dInR}$ promoters.

Interestingly, $125 \mathrm{bp}$ upstream of the transcription start site of the d4EBP promoter there are three tandem copies of a putative FOXO4 recognition element (FRE; Fig. 5E). These elements are reminiscent of the ones present in the human glucose-6-phosphatase promoter, previously shown to bind FOXO4 (Yang et al. 2002). This was reassuring because dFOXO and FOXO4 share $85 \%$ identity in the core of the forkhead DNA-binding domain (Fig. 1B). Similarly, several putative FRE sequences appear in the dInR promoter in the region comprising nucleotides -1434 to -70 (Fig. 5E).

To determine whether dFOXO binds these putative FREs, we performed band shift experiments with a 113bp DNA probe encompassing the d4EBP FRE motifs and with 12 separate DNA probes (ranging from 100 to 150 bp) spanning a region of $1.4 \mathrm{~kb}$ from the dInR promoter (Fig. 5E). Purified recombinant dFOXO expressed in Escherichia coli efficiently binds the 113-bp FRE-containing fragment from the d4EBP promoter (Fig. 5B, lanes 1-4) compared with control DNA fragments (Fig. 5B, lanes 5-8). Furthermore, dFOXO binding to the d4EBP promoter fragment can be efficiently competed with an unlabeled 113-bp d4EBP promoter fragment (Fig. 5B, lanes 9-12) but not with nonspecific DNA (Fig. 5B, lanes 13-16). Similarly, purified recombinant dFOXO binds efficiently to 5 out of 12 of the DNA fragments located within the dInR promoter (Fig. 5B, lanes 17-22; data not shown). As expected, each of the five DNA fragments bound by dFOXO contains putative FREs. Thus, dFOXO can specifically bind to both promoters in vitro. To determine whether dFOXO also binds these same DNA regions in vivo, we performed chromatin immunoprecipitation (ChIP) experiments with S2 cells expressing either dFOXO or dFOXOA3. Cells were incubated with serum, and dFOXO expression was induced with the ad- 

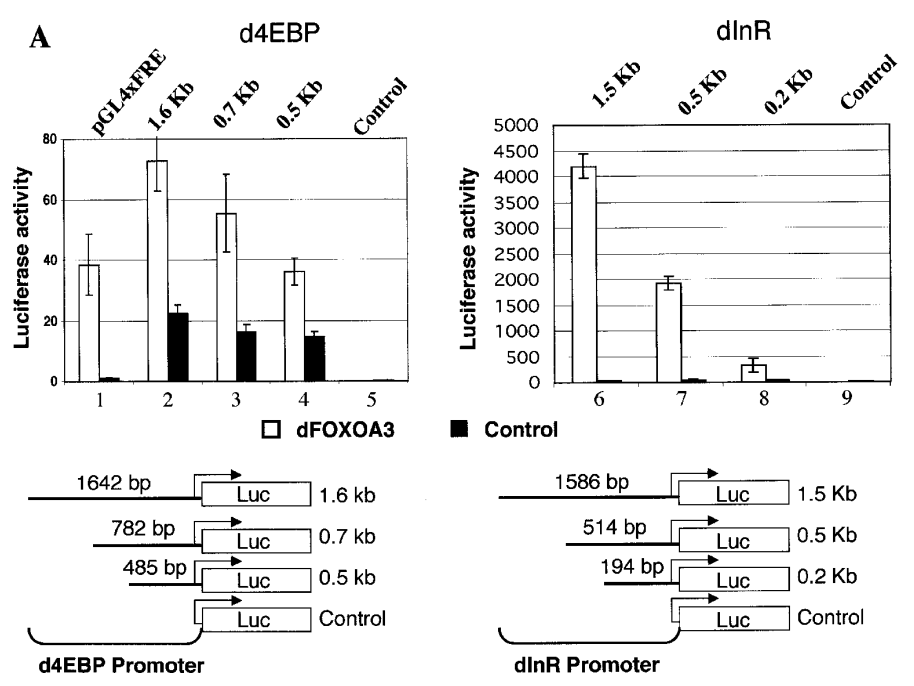

C

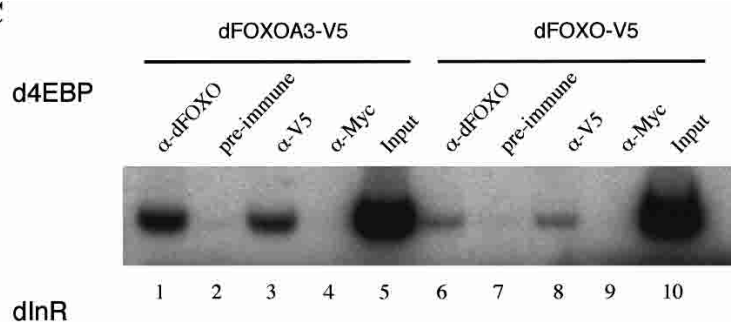

dInR

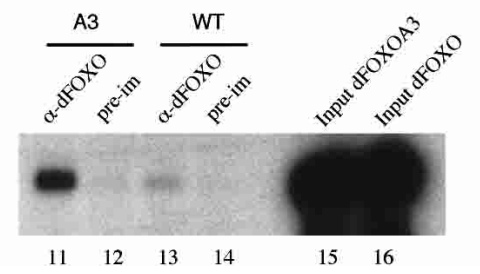

B
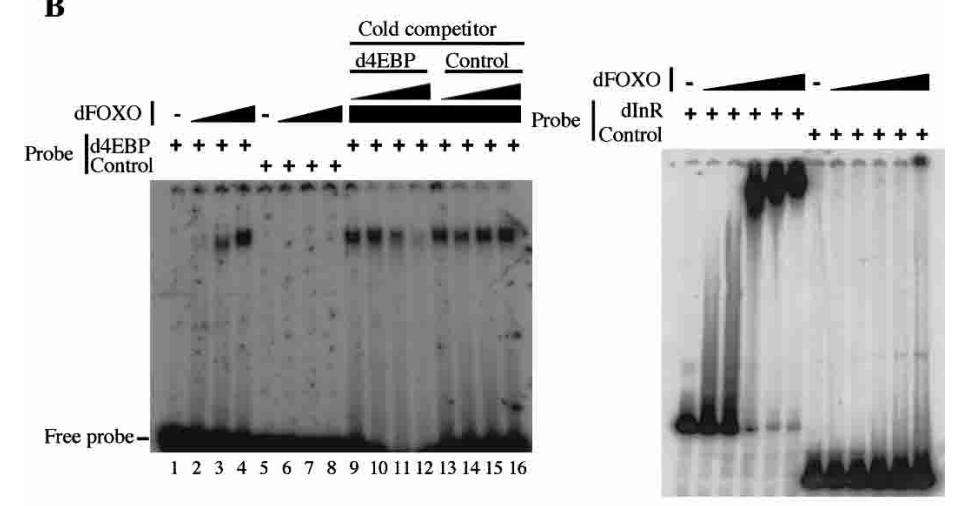

D
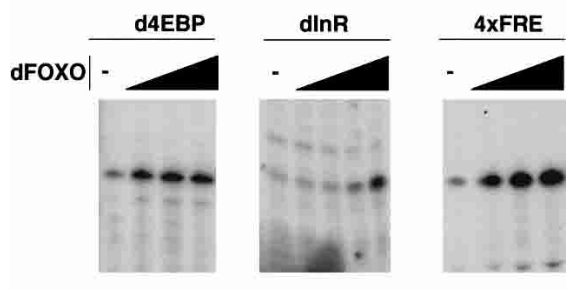

171819202122232425262728

1234

56789

10111213

$\mathbf{E}$

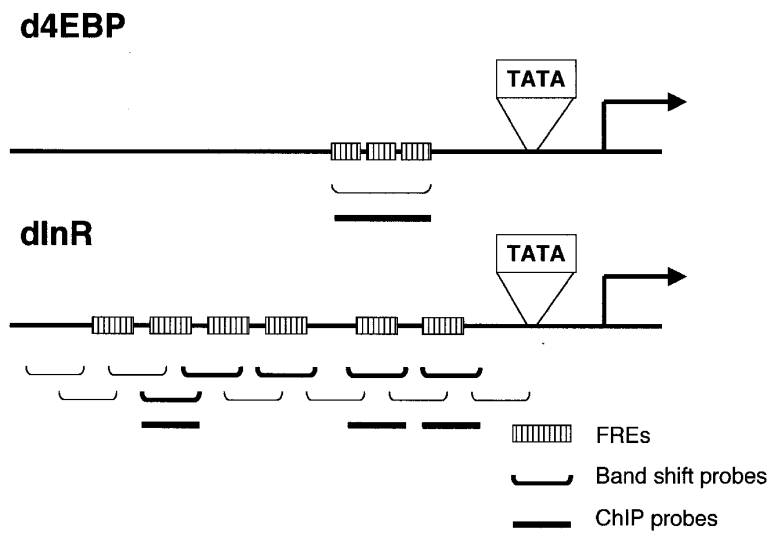

Figure 5. dFOXO directly activates transcription of dInR and d4EBP. (A) Luciferase assays showed activation of d4EBP and dInR promoters in S2 cells after cotransfection with dFOXOA3 (white bars). (Black bars) Empty vector. (B) Band shift performed with d4EBP and dInR promoters showed that recombinant dFOXO binds specifically to these promoters. $(C)$ dFOXO binds specifically to d4EBP and dInR promoters in vivo. ChIP of cross-linked extracts of S2 cells expressing dFOXO or dFOXOA3 grown in prescence of insulin. (D) Recombinant dFOXO activates transcription of d4EBP (lanes 1-4) and dInR (lanes 5-9) promoters and of a synthetic promoter bearing 4 FREs (lanes 10-13) in vitro. (E) Schematic representation of the d4EBP and dInR promoters showing the putative FREs (striped boxes) located upstream of the transcription start sites (indicated by arrows). The probes used in band shifts are indicated below as horizontal brackets, and those probes bound by dFOXO are shown as thick lines. Thick horizontal bars indicate the DNA regions bound in vivo by dFOXO as analyzed by ChIP. 
dition of $\mathrm{CuSO}_{4}$. After $6 \mathrm{~h}$, cells were cross-linked with formaldehyde, and extracts were prepared and immunoprecipitated. After reversal of cross-links, DNA was recovered, and PCR was performed with primers encompassing regions containing putative FREs in both promoters (Fig. 5E). Our results indicate that dFOXO can directly bind to both the d4EBP and dInR promoters in vivo (Fig. 5C, lanes 1,3,11; data not shown). In contrast, no specific d4EBP or dInR promoter fragments were precipitated using preimmune serum or an unrelated antibody (Fig. 5C, lanes 2,4,12). Control experiments performed with probes for the U6 snRNA promoter showed that dFOXO binding to dInR and d4EBP promoters was specific (data not shown). These results establish that dFOXO can specifically bind the d4EBP and dInR promoters both in vitro and in vivo.

To demonstrate that dFOXO can directly activate transcription of these promoters in vitro, we used the constructs that contain $485 \mathrm{bp}$ of the d4EBP promoter region and $514 \mathrm{bp}$ of the dInR promoter region, respectively. Addition of purified recombinant dFOXO to in vitro reactions activates transcription of these promoters by at least 3 -fold (d4EBP) and 5.5-fold (dInR; Fig. 5D, lanes $1,2,5,9$ ), which is comparable to the activation observed in vivo (Fig. 5A). Under our in vitro transcription conditions, activation of the d4EBP promoter by dFOXO becomes rapidly saturated with increasing amounts of dFOXO (Fig. 5D, lanes 2-4). As expected, dFOXO also activates (up to sixfold; Fig. 5D, lanes 10-13) a synthetic promoter bearing four FOXO4-binding sites placed upstream of the alcohol dehydrogenase distal promoter. Together these results show that transcription of d4EBP and dInR can be directly activated by dFOXO in vitro.

\section{dFOXO regulates organ size in Drosophila by regulating cell number}

Taken together, our data strongly suggest that dFOXO is a key regulator of the insulin signaling pathway. As expected, dFOXO activity is inhibited via the $\mathrm{dInR} / \mathrm{dPI} 3 \mathrm{~K} /$ dAkt pathway. We have also found that $\mathrm{dFOXO}$ activates transcription of a major downstream target (d4EBP) of this pathway. In Drosophila, this pathway has been linked to cell size and cell number regulation. We therefore wondered whether $\mathrm{dFOXO}$ expression in vivo would affect these same parameters. To address this point, we generated transgenic flies that overexpressed dFOXO by using the UAS/GAL4 system (Brand and Perrimon 1993). When $\mathrm{dFOXO}$ expression was directed to the eye by using eyeless-GAL4 (Hazelett et al. 1998), eyes became significantly smaller than wild type (Fig. 6A,B). Interestingly, the reduction in eye size $(35 \%)$ was caused by a reduction in cell number $(673 \pm 24$ ommatidia in control eyes vs. $438 \pm 50$ ommatidia in ey-GAL4/UAS-dFOXO), but no significant change in cell size was observed (85.8 \pm 5.9 area units/ommatidia in control eyes vs. $91.2 \pm 4.8$ area units/ommatidia in ey-GAL4/UASdFOXO). When we used GMR-GAL4, which directs expression in cells posterior to the morphogenetic furrow (Hay et al. 1994), to drive dFOXO expression, we ob- served a more severe phenotype. Many ommatidia were lost, and the remaining ommatidia lacked bristles and appeared disorganized, altering the general structure of the eye (Fig. 6C). These results suggest that dFOXO overexpression can severely affect normal development of the eye.

We next tested the effect of dFOXO overexpression in an organ other than the eye. We used $d p p-G A L 4$ (Staehling-Hampton and Hoffmann 1994) to direct expression of $\mathrm{dFOXO}$ in the wing region encompassed by the third and fourth longitudinal veins (Fig. 6D). As expected, dFOXO overexpression resulted in a significant reduction of compartment size (20\%; Fig. 6D,E). Again, we confirmed that this reduction in size was caused by a reduction in cell number but not in cell size $/ 71 \pm 7.5$ cells/area unit in the control vs. $71 \pm 5.5$ cells/area unit in $d p p-G A L 4 / U A S-d F O X O)$. Ectopic expression of dFOXO in the wing using MS1096-GAL4 (Capdevila and Guerrero 1994) produced a more striking reduction in wing size $(40 \%$; Fig. $6 \mathrm{~F}, \mathrm{G})$, again because of loss of cell number with no significant variation in cell size $(70.6 \pm 6.5$ cells/area unit in the control vs. $74.8 \pm 11.8$ cells/area unit in MS1096-GAL4/UAS-dFOXO).

We have shown that dAkt can phosphorylate and inactivate dFOXO in S2 cells (Fig. 2E). We wanted to know whether dAkt also inhibits the phenotypic effects of dFOXO in flies. We obtained flies expressing dFOXO, dAkt, or both (Fig. $6 \mathrm{H}-\mathrm{K}$ ). Indeed, dAkt expression partially rescues the eye phenotype observed with dFOXO (Fig. 6, cf. J and K), showing that they interact genetically. These results provide further evidence of both proteins acting in the same pathway.

\section{Discussion}

Feedback regulation of the insulin signaling pathway by $d F O X O$

Although a good deal has been learned about insulinregulated signal transduction pathways in mammals and other metazoans, many of the regulatory steps and mechanisms remain unclear. By studying the InR signaling pathway in Drosophila and focusing our attention on a key downstream component, the transcriptional activator dFOXO, we have uncovered novel aspects of this important signaling cascade. First, we describe the cloning and functional characterization of $\mathrm{dFOXO}$, the Drosophila homolog of DAF-16/FOXO, a transcriptional regulator of the dInR/dPI3K/dAkt pathway. Surprisingly, $\mathrm{dFOXO}$ transcriptionally activates downstream as well as upstream targets of this signaling cascade, providing the first evidence for a transcriptional feedback mechanism in the InR pathway that regulates cell growth and proliferation. Furthermore, we have found that dFOXO modulates the dInR signaling pathway by transcriptionally activating two key elements of this signaling cascade: the downstream effector d4EBP and dInR itself (Fig. 7A). Activation of dInR provides an interesting way to modulate the dInR/dPI3K/dAkt pathway via a feedback regulatory loop that may have important implications during development. 
A
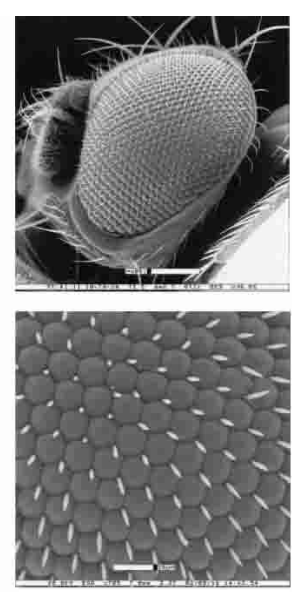

Control
B
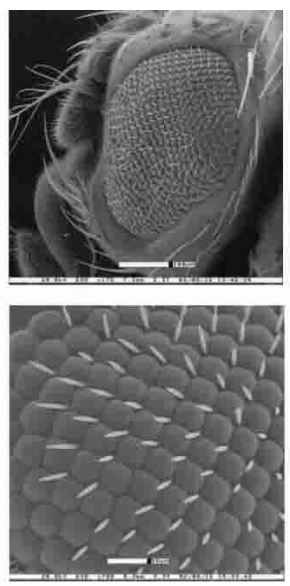

ey-dFOXO
C
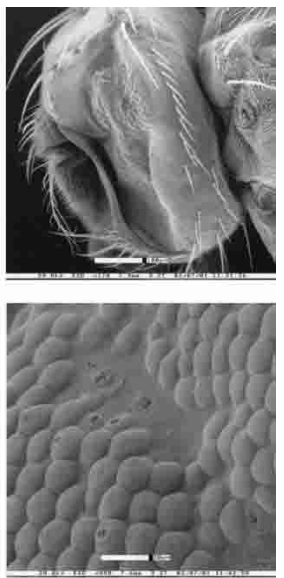

GMR-dFOXO
D
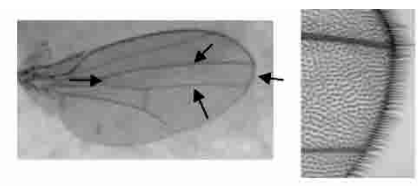

F

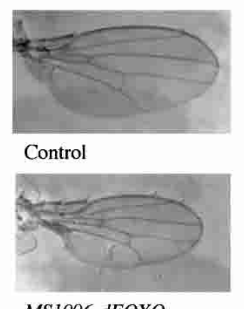

MS1096-dFOXO
Control $100 \pm 7.8 \%$

E

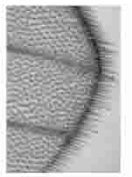

dpp-dFOXO

$79.1 \pm 5.2 \%$
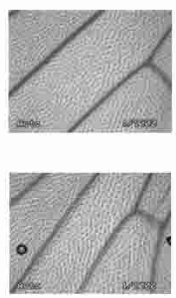

$60.4 \pm 9.8 \%$
$100 \pm 2.9 \%$
$\mathbf{H}$
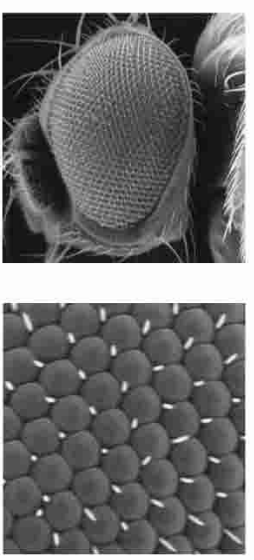

Control
I
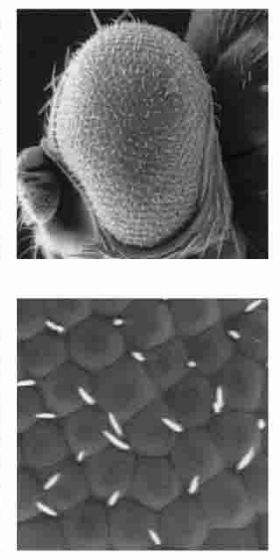

dAkt
$\mathbf{J}$
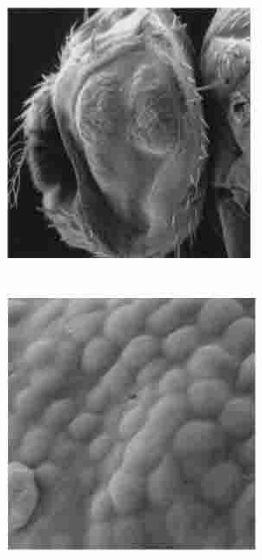

dFOXO
$\mathbf{K}$
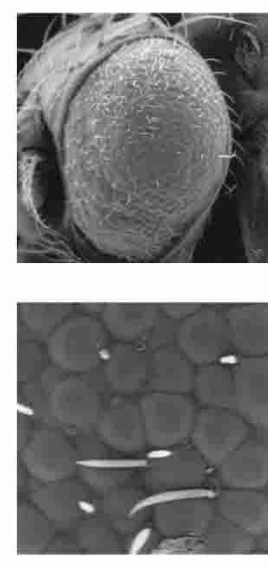

$\mathrm{dAkt}+$

Figure 6. dFOXO controls growth by affecting cell number. $(A, B)$ Expression of dFOXO in fly eyes reduces eye size without affecting ommatidia size. (A) ey-Gal4/+. (B) ey-Gal4/UAS-dFOXO. (C) Overexpression of dFOXO in eye discs before the morphogenetic furrow (GMR-Gal4/UAS-dFOXO) causes a striking reduction of the eye size with severe ommatidia loss. (D-G) Overexpression of dFOXO in fly wings causes reduction in wing size by only affecting cell number. Values are the total average area in percent. $(D) d p p-G a l 4 /+$ $(100 \% \pm 7.8 \%)$. Arrows indicate the area affected by the driver. (E) dpp-Gal4/UAS-dFOXO (79.1\% \pm 5.2\%). (F) MS1096-Gal4/+ $(100 \% \pm 2.9 \%)$. (G) MS1096-Gal4/UAS-dFOXO $(60.4 \% \pm 9.8 \%)$. (H-K) dAkt partially rescues the phenotype produced by dFOXO expression. (H) GMR-Gal4/++/+. (I) GMR-Gal4/+UAS-dAkt/+. (J) GMR-Gal4/UAS-dFOXO +/+. (K) GMR-Gal4/UAS-dFOXO UAS$d A k t /+$

It has been shown that regulation of growth during development depends on the availability of nutrients (Britton et al. 2002) and that food limitation decreases the Drosophila insulin-like peptide (DILP) levels (Ikeya et al. 2002; Rulifson et al. 2002). An activated dInR pathway promotes growth, whereas mutations in this pathway impair normal development. For instance, flies mutant for chico, which encodes the Drosophila homolog of IRS1-4, are developmentally delayed, have severely reduced body size and increased fat accumulation (Bohni et al. 1999). Likewise, mutations in several other components of the dInR pathway produce related phenotypes. Our finding that dFOXO is involved with feedback activation of dInR provides a novel mechanism for the cells to regulate growth by responding rapidly to changes in nutrient conditions. When nutrients are abundant, el- evated levels of DILPs are secreted to activate the dInR pathway, and the resulting downstream signaling promotes growth, in part by inhibiting dFOXO. These favorable nutrient conditions would allow growth and development (Fig. 7B). However, in a situation in which nutrients are limiting, DILPs would be secreted at a reduced rate, the dInR pathway would not be activated, and $\mathrm{dFOXO}$ would remain dephosphorylated, nuclear, and active. As a result, growth would be inhibited, in part by dFOXO activation of d4EBP. On the other hand, because $\mathrm{dFOXO}$ would be active when nutrients are limited, dInR becomes up-regulated and primed to signal when triggered by changes in DILPs levels. In this way, when nutrient conditions change, the cells would be highly sensitized and able to respond rapidly by turning on the mechanisms that stimulate growth, including 
Puig et al.
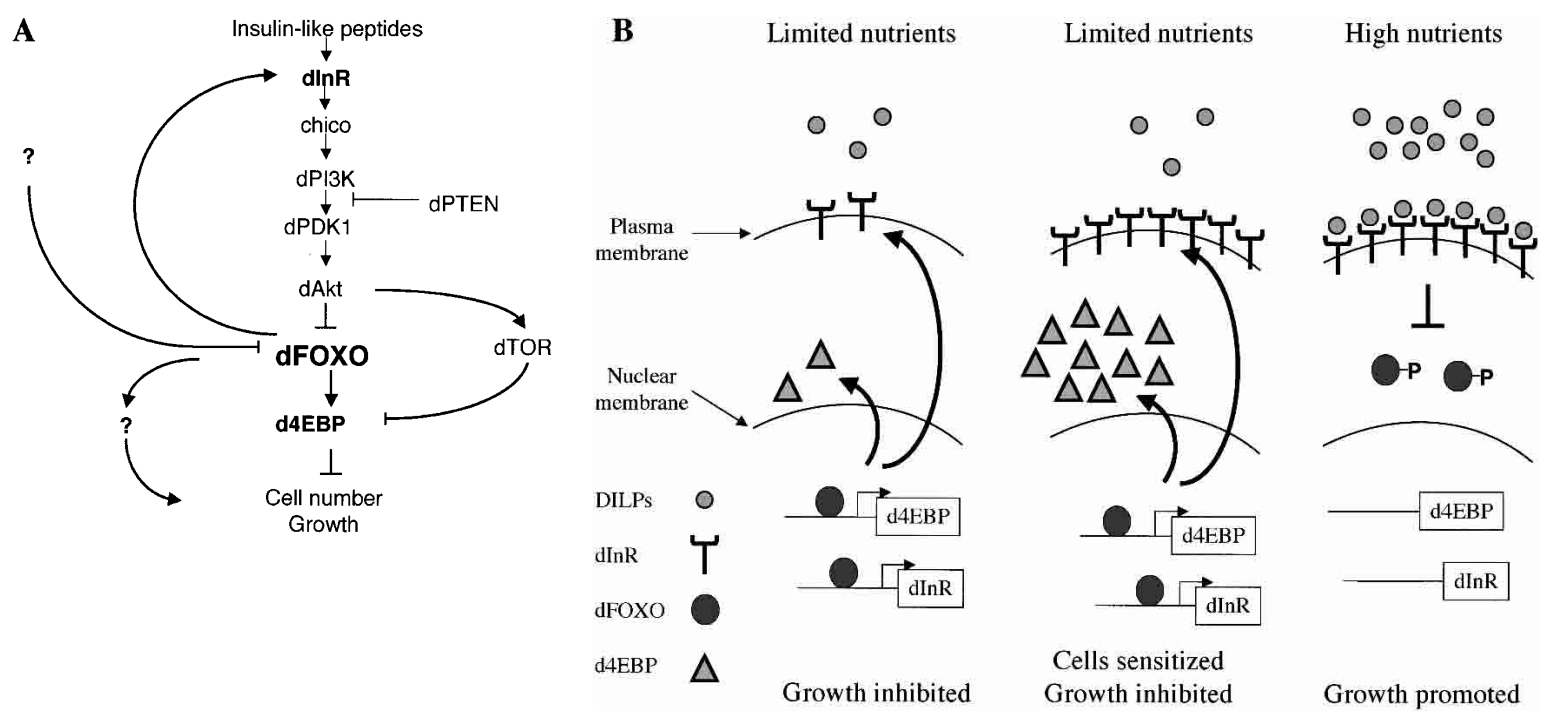

Figure 7. (A) dFOXO is a key element of insulin signaling in Drosophila. The insulin receptor inactivates dFOXO through dPI3K/ dAkt. Activation of d4EBP may explain growth inhibition by dFOXO, whereas activation of dInR may provide a novel transcriptionally induced feedback control mechanism for the pathway. (B) Model to explain regulation of growth by a feedback mechanism involving dInR and dFOXO.

shutting down dFOXO via dAkt phosphorylation. In addition, dFOXO-mediated dInR transcriptional activation presents a highly sensitive way to regulate the dInR/ dPI3K/dAkt signaling pathway in response to subtle developmental cues that modulate DILP levels. High levels of DILPs would activate dInR, which would lead to the inhibition of its own transcription, turning off the pathway. Conversely, reduced levels of DILPs would activate dInR transcription. This would sensitize the pathway and provide a mechanism to amplify growth factor signals by allowing detection of lower levels of DILPs. Once this pathway is activated, feedback regulation via dFOXO would dampen dInR expression and signaling. Growth and development through the dInR pathway could thus be exquisitely balanced and regulated. Interestingly, overexpression of dFOXO under the control of strong promoters (GMR, tubulin) in flies results in severe morphological defects (Fig. 6C; data not shown). These results suggest that abnormally high levels of dFOXO may produce growth arrest in developing organs. Surprisingly, flies with loss-of-function mutations in dFOXO appear to develop normally ( $M$. Jünger and $\mathrm{E}$. Hafen, pers. comm.), indicating that dFOXO is not essential during fly development. These results suggest the existence of additional mechanisms that modulate insulin signaling and underscore the complexity of such developmental pathways.

\section{dAkt inhibits d4EBP activity and down-regulates its transcription via $d F O X O$}

In mammals, it has been reported that Akt promotes protein synthesis through TOR-mediated phosphorylation and subsequent inactivation of the translational inhibitor 4EBP. Hypophosphorylated 4EBP interacts strongly with eIF4E, providing a mechanism for Akt to regulate 4EBP via TOR (Gingras et al. 1998, 1999). In flies, a similar mechanism has been reported (Miron et al. 2001). In contrast, the role of dFOXO in transcriptionally modulating d4EBP has not been previously described. Our finding that $\mathrm{dFOXO}$ directly regulates d4EBP transcription provides an alternative and parallel mechanism for dAkt to inhibit d4EBP function. Under conditions in which the insulin pathway is active, dAkt sequesters dFOXO in the cytoplasm, and d4EBP transcription is turned off. When the dInR/dPI3K/dAkt pathway is inactive, $\mathrm{dFOXO}$ is free to stimulate transcription of d4EBP and inhibit protein synthesis. It has been previously reported that overexpression of 4EBP slows growth in mammalian cells (Rousseau et al. 1996), and now we have shown that dFOXO overexpression leads to growth arrest in Drosophila S2 cells. It is therefore likely that up-regulation of $\mathrm{d} 4 \mathrm{EBP}$ by $\mathrm{dFOXO}$ contributes to the observed growth arrest. However, we cannot rule out additional mechanisms (i.e., induction of apoptosis by dFOXO), which could also contribute to the observed phenotype.

\section{dFOXO regulates cell number without affecting cell size}

It has been well documented that the dInR/dPI3K/dAkt pathway regulates cell number and cell size in Drosophila. However, the precise mechanisms by which the insulin pathway controls these parameters remain unknown. Mutations in some members of this pathway affect cell size as well as cell number, whereas mutations in other members appear to affect only cell size. For example, mutations in both $d \operatorname{In} R$ and $d P I 3 K$ produce smaller flies with reduced numbers of cells and smaller 
cell size (Leevers et al. 1996; Bohni et al. 1999). Mutations in the negative regulator $A P T E N$ produce bigger cells and increased proliferation (Gao et al. 2000). In contrast, mutations in $d A k t$ produce smaller organs without affecting cell number, only cell size (Verdu et al. 1999). Overexpression of mutant d4EBP with increased binding affinity for eIF4E produces flies with smaller and fewer cells (Miron et al. 2001). Thus, until now, none of the components of the dInR pathway has been found to regulate only cell number without influencing cell size. It was therefore intriguing to find that overexpression of dFOXO produces a reduction in cell number without any measurable effect on cell size. This is reminiscent of the transcription factor $\mathrm{c}-\mathrm{myc}$, which in mammals regulates cell number without altering cell size (Trumpp et al. 2001) but in Drosophila affects both cell size and number (Johnston and Gallant 2002). Taken together, these results reveal the species specific complexity of the mechanisms that regulate cell growth and proliferation. Indeed, our results suggest that the InR/PI3K/Akt pathway is far from being a simple linear cascade. Instead, dAkt appears to regulate numerous targets, each one with its own set of downstream effectors. In addition, it is conceivable that $\mathrm{dFOXO}$ may be regulated by kinases other than dAkt. In mammals, FOXO4 has been shown to be regulated by the Ras/MAP kinase pathway (Kops et al. 1999), and a similar mechanism may exist in flies. Interestingly, our microarray experiments identified $>200$ genes in addition to d4EBP that are up-regulated by dFOXO (data not shown), which increases the complexity of transcriptional regulation affected by dFOXO. Additional studies will be necessary to determine the multiple mechanisms by which the insulin signaling cascade dictates cell number and size during development of the metazoan body plan.

\section{Materials and methods}

Constructs, Drosophila strains, and antibodies

Clones LD05569 and LD19191 contain the complete cDNA of dFOXO (accession no. AF426831). dFOXO was cloned in pMTV5-HisA (Invitrogen), giving pMTdFOXO. QuikChange (Stratagene) was used to mutate the three Akt phosphorylation sites, producing pMTdFOXOA3. Clone SD10374 containing full-length dAkt was subcloned in pAc5V5-HisA (Invitrogen). An $s r c$ myristoylation signal (MGSSKSKPK) was added at the $\mathrm{N}$ terminus by PCR, giving the pAcMyrdAkt vector. The luciferase reporter pGL4xFRE was constructed by inserting the ADH distal promoter $(-42$ to +40$)$ in pGL3Basic (Promega). Four FOXO4-binding sites (AGTTTGTTTGTCGATTAAATAAA CATGTAAACACTTTGTTTTGTTGATACAAACAAAA) were added upstream by PCR. A DNA fragment of the d4EBP promoter $(-1460$ to +197$)$ and a 1586-bp DNA fragment of the dInR promoter were amplified by PCR and cloned in pGL3Basic, producing pGLd4EBP1.6 and pGLdInR1.5, respectively. Shorter versions of these DNA fragments were produced in a similar way. As negative control, a construct containing Upstream Activating Sequences (UAS) for the transcription factor GAL4 and an E1B TATA sequence upstream of a luciferase reporter gene was used. This construct was activated by GAL4 but not by dFOXO. All the constructs were verified by sequencing.
dFOXO-V5 was subcloned in a pUAST vector, and transgenic flies were obtained by injecting the construct into $y w$ recipients. Four independent lines were established. UAS-dFOXOA3 was injected in the same way; however, no transformant line could be obtained for this construct. $w$; UAS-dAkt flies were a kind gift from Morris Birnbaum (Howard Hughes Medical Institute, University of Pennsylvania, Philadelphia, PA; Verdu et al. 1999). y1 $\mathrm{W}^{*} ; \mathrm{wg}^{S p-1} / C y O ; P\left\{\mathrm{w}^{+m W} \cdot h s=G A L 4-d p p \cdot b 1 k 1\right\} 40 C .6 /$ MKRS (Bloomington 1553b) was obtained from the Bloomington Stock Center. MS1096 (Capdevila and Guerrero 1994) was a gift from Y. Nibu (Division of Genetics and Development, Department of Molecular and Cell Biology, University of California, Berkeley, CA). ey-GAL4 (Hazelett et al. 1998) and GMRGAL4 (Hay et al. 1994) were obtained from L. Michaut (Biozentrum, University of Basel, Basel, Switzerland).

Antibodies were raised in rabbits against amino acids 1-213 and $214-613$ of dFOXO.

\section{Cell culture and extract preparation}

Drosophila Schneider line S2 cells (ATCC CRL-1963) were grown in M3 medium (Sigma) with $10 \%$ heat-inactivated fetal bovine serum, penicillin, and streptomycin at $25^{\circ} \mathrm{C}$ in suspension. Stable transfected S2 cells were grown in the presence of $300 \mu \mathrm{g} / \mathrm{mL}$ hygromycin (Clontech). To remove serum from the medium, cells were pelleted and washed once with phosphate buffer saline (PBS). Then cells were incubated in M3 medium without serum for at least $48 \mathrm{~h}$. Next, $1 \times 10^{6}$ cells were plated per well in a 24 -well plate. Treatments with insulin $(1 \mu \mathrm{g} / \mathrm{mL}$; Roche) dissolved in $\mathrm{H}_{2} \mathrm{O}$ or LY294002 (20 $\mu \mathrm{M}$; Calbiochem) dissolved in ethanol were performed by incubating the cells for $6 \mathrm{~h}$ prior to manipulation. In Figure 1F, insulin was incubated for 40 min and LY294002 for 10 min prior to insulin treatment. Extracts were obtained by washing S2 cells with PBS and resuspending them in passive lysis buffer (Promega).

\section{Transfection}

For transfection, $1 \times 10^{6} \mathrm{~S} 2$ cells were plated per well in a 24 well plate. Cells were transfected using effectene reagent (QIAGEN). For this, $200 \mathrm{ng}$ of expression vector (pMTdFOXO, pMTdFOXOA3, or pMTV5-HisA), $50 \mathrm{ng}$ of reporter vector (pGL4xFRE, pGLdInR1.5, or pGLd4EBP1.6), and 50 ng of pAcMyrdAkt (when necessary) were used. Stable transfectants for pMTdFOXO or pMTdFOXOA3 were obtained as recommended (Invitrogen), and $600 \mu \mathrm{M} \mathrm{CuSO}_{4}$ was used to induce dFOXO or dFOXOA3 expression.

\section{Phosphatase treatment and Western blot}

Western blot detection and phosphatase treatment were performed as described (Miron et al. 2001). Membranes were probed with anti-dFOXO (1:1000), anti-V5 (1:5000; Invitrogen), or anti-tubulin (1:10.000; Sigma).

\section{Immunolocalization}

S2 cells grown in M3 medium without serum were grown on coverslips and incubated for $6 \mathrm{~h}$ ( \pm insulin). Cells were washed with PBS, fixed with $2 \%$ formaldehyde in PBS for $10 \mathrm{~min}$, and permeabilized with $0.1 \%$ saponin in PBS for $20 \mathrm{~min}$. Cells were stained with anti-V5 antibody (1:5000 dilution) and anti-mouse Alexa 488 (1:200; Molecular Probes). Cells were mounted with vectashield containing DAPI $(5 \mu \mathrm{g} / \mathrm{mL})$ for observation under a confocal microscope (LSM510, Zeiss). 


\section{Cell growth analysis}

Cultures of cells stably transfected with constructs pMTdFOXO or pMTdFOXOA3 were seeded at $0.5 \times 10^{6}$ cells $/ \mathrm{mL}$ in the presence of serum and insulin. $\mathrm{CuSO}_{4}$ was added $48 \mathrm{~h}$ later and then removed after another $8 \mathrm{~h}$ by pelleting the cells and washing them in PBS. Cells were pelleted again and resuspended in M3 medium with serum and insulin. At this point and every $12 \mathrm{~h}$ after, cells were counted. The data in Figure 3 are representative of three independent experiments. Western blotting was performed with V5 antibody for each 24-h time point to detect dFOXO or dFOXOA3 levels. FACS analysis was performed for every 24-h time point. Briefly, cells were washed with PBS, fixed in $90 \%$ ethanol, and kept at $-20^{\circ} \mathrm{C}$ until all samples were collected. An equal number of cells for each point was resuspended in $800 \mu \mathrm{L}$ of PBS, and $100 \mu \mathrm{L}$ of RNAse $\mathrm{A}(10 \mathrm{mg} / \mathrm{mL})$ and $50 \mu \mathrm{L}$ of propidium iodide $(1 \mathrm{mg} / \mathrm{mL})$ were added. Cells were incubated at $37^{\circ} \mathrm{C}$ for $1 \mathrm{~h}$. Flow cytometry analysis was performed with a Beckman-Coulter XL apparatus.

\section{RNA interference}

Nucleotides 850-1590 of dAkt or the full-length E. coli lacI gene were cloned in pCR4 Topo (Invitrogen) and transcribed independently with T7 and T3 RNApol. Equal molar amounts of each RNA strand were annealed by heating at $65^{\circ} \mathrm{C}$ for $30 \mathrm{~min}$ and cooling slowly to room temperature. Then $5 \mu \mathrm{g}$ of dsRNA was used per well in a 24-well plate. dsRNAs were added and cells were incubated at $25^{\circ} \mathrm{C}$ for $2 \mathrm{~d}$. Subsequently, cells were transfected, and luciferase activity was measured as described before.

\section{DNA microarrays}

Cells stably transfected with pMTdFOXO or pMTdFOXOA3, or untransfected S2 cells, were grown in suspension in M3 medium in the presence of serum and insulin. After $6 \mathrm{~h}$ of $\mathrm{CuSO}_{4}$ induction, cells were pelleted, and total RNA was extracted with Trizol (Invitrogen). cRNA synthesized from total mRNA was used to probe Affymetrix microarrays containing 13,500 Drosophila transcripts. When necessary, cycloheximide ( $35 \mu \mathrm{M})$ was added $2 \mathrm{~h}$ after induction and incubated for $5 \mathrm{~h}$. All steps for microarray analysis were done following protocols by Affymetrix. Genes activated by dFOXO were defined as genes upregulated in dFOXOA3 cells but not in dFOXO or S2 cells.

\section{RNase protection}

RNase protection assays were carried out with the RPAIII kit (Ambion). DNA fragments including exonic and intronic sequences of d4EBP, dInR, actin, and 18s rRNA were amplified by $\mathrm{PCR}$ and cloned in pBluescript II SK+ (Stratagene) for in vitro transcription; $10 \mu \mathrm{g}$ of total RNA was used per sample. The experiment of Figure $4 \mathrm{C}$ was performed by incubating dFOXO or dFOXOA3 transfected cells with or without $\mathrm{CuSO}_{4}$ and with or without insulin for $6 \mathrm{~h}$. To analyze endogenous dFOXO activity, S2 cells were grown in the absence of serum for $48 \mathrm{~h}$. Then insulin or LY294002 was added, and $6 \mathrm{~h}$ later, total RNA was extracted and analyzed by RNase protection as described above.

\section{Band shift analysis}

Band shift experiments were performed with a DNA fragment of 113 bp spanning nucleotides -190 to -77 of the d4EBP promoter. A 107-bp fragment from the multiple cloning site of pBluescript SK II (between $X b a I$ and $X$ hoI sites) was blunt-ended and used as negative control. For analysis of the dInR, DNA fragments -21119, -94-194, -172-273, -249-369, -346-514, -488-627, -597$854,-828-980,-955-1128,-1103-1216,-1193-1435$, and -1410-1586 were used. Binding reactions were performed as described (Coleman and Pugh 1997) with labeled probe (20 nM), increasing amounts of recombinant purified dFOXO (40-600 $\mathrm{nM}$ ), and cold competitor (200 nM to $2 \mu \mathrm{M}$ ). Complexes were resolved on $4.35 \%$ polyacrylamide $(37: 1), 2.5 \%$ glycerol, $1 \times$ TBE, and $4 \mathrm{mM} \mathrm{MgCl}_{2}$ at $4^{\circ} \mathrm{C}$.

\section{Chromatin immunoprecipitation}

Samples were treated as described (Andrulis et al. 2000) except no $\mathrm{CsCl}$ gradient was performed. Instead, samples were diluted 1:10 with PBS prior to immunoprecipitation.

\section{In vitro transcription}

Drosophila nuclear extract was prepared essentially as described (Biggin and Tjian 1988). The H.4 fraction was immunodepleted of endogenous dFOXO by incubation with Protein-A Sepharose beads containing antibodies raised against the $\mathrm{N}$ terminus of dFOXO. Transcription analysis was performed by primer extension as described (Hansen et al. 1997).

\section{Fly analysis, cell count, and area measurements}

All measurements were done with females. Electron micrographs were taken following standard protocols (Bozzola and Russell 1999). Ommatidia were counted in eight (mutant) or seven (control) flies. Seven ommatidia were taken from each eye to calculate their area by using the histogram function of Adobe Photoshop. Wings were analyzed as described (Miron et al. 2001). A total of $30(d p p)$ and 15 (MS1096) wings were counted for either phenotype.

\section{Acknowledgments}

We thank M. Birnbaum, L. Michaut, Y. Nibu, and the Bloomington Drosophila Stock center for fly strains; Y. Isogai for help with confocal microscopy; G. Vrdoljak from the Electron Microscopy Laboratory at UC Berkeley for his help with electron microscopy; D. Schichnes from the Biological Imaging Facility for helping with the confocal and optical imaging; and H. Nolla from the Flow Cytometry Facility for helping with FACS. We also thank R. Freiman, K. Geles, B. Glover, M. Jünger, Y. Isogai, W-L. Liu, S. Martin, D. Rio, D. Taatjes, B. Weinert, and J. Ziegelbauer for comments on the manuscript. Members of the Tijian and Levine labs are acknowledged for helpful ideas and technical assistance. O.P. is supported by EMBO and HHMI postdoctoral fellowships. M.T.M. is supported by a fellowship from the Damon Runyon Cancer Research Foundation (DRG-\#1684). This work was funded by grants from the NIH and the Howard Hughes Medical Institute to R.T.

The publication costs of this article were defrayed in part by payment of page charges. This article must therefore be hereby marked "advertisement" in accordance with 18 USC section 1734 solely to indicate this fact.

\section{Note added in proof}

Recent work by Jünger et al. (2003) reports similar findings that $\mathrm{dFOXO}$ is a major regulator on the insulin signaling pathway in Drosophila. 


\section{References}

Alvarez, B., Martinez, A.C., Burgering, B.M., and Carrera, A.C. 2001. Forkhead transcription factors contribute to execution of the mitotic programme in mammals. Nature 413: 744747.

Andrulis, E.D., Guzman, E., Doring, P., Werner, J., and Lis, J.T. 2000. High-resolution localization of Drosophila Spt5 and Spt6 at heat shock genes in vivo: Roles in promoter proximal pausing and transcription elongation. Genes \& Dev. 14: $2635-2649$.

Ayala, J.E., Streeper, R.S., Desgrosellier, J.S., Durham, S.K., Suwanichkul, A., Svitek, C.A., Goldman, J.K., Barr, F.G., Powell, D.R., and O'Brien, R.M. 1999. Conservation of an insulin response unit between mouse and human glucose-6-phosphatase catalytic subunit gene promoters: Transcription factor FKHR binds the insulin response sequence. Diabetes 48: $1885-1889$.

Biggin, M.D. and Tjian, R. 1988. Transcription factors that activate the Ultrabithorax promoter in developmentally staged extracts. Cell 53: 699-711.

Bohni, R., Riesgo-Escovar, J., Oldham, S., Brogiolo, W., Stocker, H., Andruss, B.F., Beckingham, K., and Hafen, E. 1999. Autonomous control of cell and organ size by CHICO, a Drosophila homolog of vertebrate IRS1-4. Cell 97: 865-875.

Bozzola, J.J. and Russell, L.D. 1999. Electron microscopy, principles and techniques for biologists, 2nd ed. Jones and Bartlett, Sudbury, MA.

Brand, A.H. and Perrimon, N. 1993. Targeted gene expression as a means of altering cell fates and generating dominant phenotypes. Development 118: 401-415.

Britton, J.S., Lockwood, W.K., Li, L., Cohen, S.M., and Edgar, B.A. 2002. Drosophila's insulin/PI3-kinase pathway coordinates cellular metabolism with nutritional conditions. Dev. Cell 2: 239-249.

Brogiolo, W., Stocker, H., Ikeya, T., Rintelen, F., Fernandez, R., and Hafen, E. 2001. An evolutionarily conserved function of the Drosophila insulin receptor and insulin-like peptides in growth control. Curr. Biol. 11: 213-221.

Brunet, A., Bonni, A., Zigmond, M.J., Lin, M.Z., Juo, P., Hu, L.S., Anderson, M.J., Arden, K.C., Blenis, J., and Greenberg, M.E. 1999. Akt promotes cell survival by phosphorylating and inhibiting a Forkhead transcription factor. Cell 96: 857-868.

Burgering, B.M. and Kops, G.J. 2002. Cell cycle and death control: Long live Forkheads. Trends Biochem. Sci. 27: 352-360.

Cantley, L.C. 2002. The phosphoinositide 3-kinase pathway. Science 296: 1655-1657.

Capdevila, J. and Guerrero, I. 1994. Targeted expression of the signaling molecule decapentaplegic induces pattern duplications and growth alterations in Drosophila wings. EMBO $J$. 13: 4459-4468.

Chen, C., Jack, J., and Garofalo, R.S. 1996. The Drosophila insulin receptor is required for normal growth. Endocrinology 137: 846-856.

Coleman, R.A. and Pugh, B.F. 1997. Slow dimer dissociation of the TATA binding protein dictates the kinetics of DNA binding. Proc. Natl. Acad. Sci. 94: 7221-7226.

Datta, S.R., Brunet, A., and Greenberg, M.E. 1999. Cellular survival: A play in three Akts. Genes \& Dev. 13: 2905-2927.

Dijkers, P.F., Medema, R.H., Lammers, J.W., Koenderman, L., and Coffer, P.J. 2000. Expression of the pro-apoptotic Bcl-2 family member Bim is regulated by the forkhead transcription factor FKHR-L1. Curr. Biol. 10: 1201-1204.

Durham, S.K., Suwanichkul, A., Scheimann, A.O., Yee, D., Jackson, J.G., Barr, F.G., and Powell, D.R. 1999. FKHR binds the insulin response element in the insulin-like growth fac- tor binding protein-1 promoter. Endocrinology 140: 3140 3146.

Fernandez, R., Tabarini, D., Azpiazu, N., Frasch, M., and Schlessinger, J. 1995. The Drosophila insulin receptor homolog: A gene essential for embryonic development encodes two receptor isoforms with different signaling potential. EMBO J. 14: 3373-3384.

Finch, C.E. and Ruvkun, G. 2001. The genetics of aging. Annu. Rev. Genomics Hum. Genet. 2: 435-462.

Gao, X., Neufeld, T.P., and Pan, D. 2000. Drosophila PTEN regulates cell growth and proliferation through PI3K-dependent and -independent pathways. Dev. Biol. 221: 404-418.

Gingras, A.C., Kennedy, S.G., O'Leary, M.A., Sonenberg, N., and Hay, N. 1998. 4E-BP1, a repressor of mRNA translation, is phosphorylated and inactivated by the Akt(PKB) signaling pathway. Genes \& Dev. 12: 502-513.

Gingras, A.C., Gygi, S.P., Raught, B., Polakiewicz, R.D., Abraham, R.T., Hoekstra, M.F., Aebersold, R., and Sonenberg, N. 1999. Regulation of 4E-BP1 phosphorylation: A novel twostep mechanism. Genes \& Dev. 13: 1422-1437.

Gingras, A.C., Raught, B., and Sonenberg, N. 2001. Regulation of translation initiation by FRAP/mTOR. Genes \& Dev. 15: 807-826.

Guo, S., Rena, G., Cichy, S., He, X., Cohen, P., and Unterman, T. 1999. Phosphorylation of serine 256 by protein kinase $B$ disrupts transactivation by FKHR and mediates effects of insulin on insulin-like growth factor-binding protein-1 promoter activity through a conserved insulin response sequence. J. Biol. Chem. 274: 17184-17192.

Hall, R.K., Yamasaki, T., Kucera, T., Waltner-Law, M., O'Brien, R., and Granner, D.K. 2000. Regulation of phosphoenolpyruvate carboxykinase and insulin-like growth factor-binding protein-1 gene expression by insulin. The role of winged helix/forkhead proteins. J. Biol. Chem. 275: 30169-30175.

Hansen, S.K., Takada, S., Jacobson, R.H., Lis, J.T., and Tjian, R. 1997. Transcription properties of a cell type-specific TATAbinding protein, TRF. Cell 91: 71-83.

Hartwell, L.H., Culotti, J., Pringle, J.R., and Reid, B.J. 1974. Genetic control of the cell division cycle in yeast. Science 183: 46-51.

Hay, B.A., Wolff, T., and Rubin, G.M. 1994. Expression of baculovirus P35 prevents cell death in Drosophila. Development 120: 2121-2129.

Hazelett, D.J., Bourouis, M., Walldorf, U., and Treisman, J.E. 1998. decapentaplegic and wingless are regulated by eyes absent and eyegone and interact to direct the pattern of retinal differentiation in the eye disc. Development 125: 37413751.

Hekimi, S., Lakowski, B., Barnes, T.M., and Ewbank, J.J. 1998. Molecular genetics of life span in C. elegans: How much does it teach us? Trends Genet. 14: 14-20.

Ikeya, T., Galic, M., Belawat, P., Nairz, K., and Hafen, E. 2002. Nutrient-dependent expression of insulin-like peptides from neuroendocrine cells in the CNS contributes to growth regulation in Drosophila. Curr. Biol. 12: 1293.

Johnston, L.A. and Gallant, P. 2002. Control of growth and organ size in Drosophila. Bioessays 24: 54-64.

Johnston, G.C., Pringle, J.R., and Hartwell, L.H. 1977. Coordination of growth with cell division in the yeast Saccharomyces cerevisiae. Exp. Cell Res. 105: 79-98.

Jünger, M.A., Rintelen, F., Stocker, H., Radimerski, T., Wasserman, J.D., Greenberg, M.E., and Hafen, E. 2003. Drosophila FOXO is not essential for size control but mediates growth inhibition associated with reduced insulin signaling. J. Biol. (in press).

Kops, G.J., de Ruiter, N.D., De Vries-Smits, A.M., Powell, D.R., 
Puig et al.

Bos, J.L., and Burgering, B.M. 1999. Direct control of the Forkhead transcription factor AFX by protein kinase B. $\mathrm{Na}$ ture 398: 630-634.

Kozma, S.C. and Thomas, G. 2002. Regulation of cell size in growth, development and human disease: PI3K, PKB and S6K. Bioessays 24: 65-71.

Lee Jr., J.T. and McCubrey, J.A. 2002. The Raf/MEK/ERK signal transduction cascade as a target for chemotherapeutic intervention in leukemia. Leukemia 16: 486-507.

Leevers, S.J., Weinkove, D., MacDougall, L.K., Hafen, E., and Waterfield, M.D. 1996. The Drosophila phosphoinositide 3-kinase Dp110 promotes cell growth. EMBO J. 15: 65846594.

Lin, K., Dorman, J.B., Rodan, A., and Kenyon, C. 1997. daf-16: An HNF-3/forkhead family member that can function to double the life-span of Caenorhabditis elegans. Science 278: 1319-1322.

Miron, M., Verdu, J., Lachance, P.E., Birnbaum, M.J., Lasko, P.F., and Sonenberg, N. 2001. The translational inhibitor 4E$\mathrm{BP}$ is an effector of $\mathrm{PI}_{3} \mathrm{~K} /$ Akt signalling and cell growth in Drosophila. Nat. Cell Biol. 3: 596-601.

Nadal, A., Marrero, P.F., and Haro, D. 2002. Down-regulation of the mitochondrial 3-hydroxy-3-methylglutaryl-CoA synthase gene by insulin: The role of the forkhead transcription factor FKHRL1. Biochem. J. 366: 289-297.

Nakae, J., Kitamura, T., Silver, D.L., and Accili, D. 2001. The forkhead transcription factor Foxol (Fkhr) confers insulin sensitivity onto glucose-6-phosphatase expression. J. Clin. Invest. 108: 1359-1367.

Nasrin, N., Ogg, S., Cahill, C.M., Biggs, W., Nui, S., Dore, J., Calvo, D., Shi, Y., Ruvkun, G., and Alexander-Bridges, M.C. 2000. DAF-16 recruits the CREB-binding protein coactivator complex to the insulin-like growth factor binding protein 1 promoter in HepG2 cells. Proc. Natl. Acad. Sci. 97: 1041210417.

Ogg, S., Paradis, S., Gottlieb, S., Patterson, G.I., Lee, L., Tissenbaum, H.A., and Ruvkun, G. 1997. The Fork head transcription factor DAF-16 transduces insulin-like metabolic and longevity signals in C. elegans. Nature 389: 994-999.

Rousseau, D., Gingras, A.C., Pause, A., and Sonenberg, N. 1996. The eIF4E-binding proteins 1 and 2 are negative regulators of cell growth. Oncogene 13: 2415-2420.

Rulifson, E.J., Kim, S.K., and Nusse, R. 2002. Ablation of insulin-producing neurons in flies: Growth and diabetic phenotypes. Science 296: 1118-1120.

Schmoll, D., Walker, K.S., Alessi, D.R., Grempler, R., Burchell, A., Guo, S., Walther, R., and Unterman, T.G. 2000. Regulation of glucose-6-phosphatase gene expression by protein kinase $\mathrm{B} \alpha$ and the forkhead transcription factor FKHR. Evidence for insulin response unit-dependent and -independent effects of insulin on promoter activity. I. Biol. Chem. 275: 36324-36333.

Staehling-Hampton, K. and Hoffmann, F.M. 1994. Ectopic decapentaplegic in the Drosophila midgut alters the expression of five homeotic genes, dpp, and wingless, causing specific morphological defects. Dev. Biol. 164: 502-512.

Stocker, H. and Hafen, E. 2000. Genetic control of cell size. Curr. Opin. Genet. Dev. 10: 529-535.

Trumpp, A., Refaeli, Y., Oskarsson, T., Gasser, S., Murphy, M., Martin, G.R., and Bishop, J.M. 2001. c-Myc regulates mammalian body size by controlling cell number but not cell size. Nature 414: 768-773.

Verdu, J., Buratovich, M.A., Wilder, E.L., and Birnbaum, M.J. 1999. Cell-autonomous regulation of cell and organ growth in Drosophila by Akt/PKB. Nat. Cell Biol. 1: 500-506.

Weigmann, K., Cohen, S.M., and Lehner, C.F. 1997. Cell cycle progression, growth and patterning in imaginal discs despite inhibition of cell division after inactivation of Drosophila Cdc2 kinase. Development 124: 3555-3563.

Yang, Z., Whelan, J., Babb, R., and Bowen, B.R. 2002. An mRNA splice variant of the AFX gene with altered transcriptional activity. J. Biol. Chem. 277: 8068-8075. 


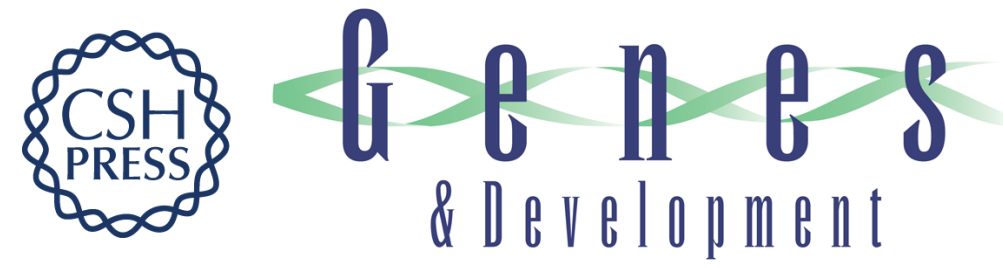

\section{Control of cell number by Drosophila FOXO: downstream and feedback regulation of the insulin receptor pathway}

Oscar Puig, Michael T. Marr, M. Laure Ruhf, et al.

Genes Dev. 2003, 17:

Access the most recent version at doi:10.1101/gad.1098703

References This article cites 52 articles, 20 of which can be accessed free at: http://genesdev.cshlp.org/content/17/16/2006.full.html\#ref-list-1

License

Email Alerting

Receive free email alerts when new articles cite this article - sign up in the box at the top Service right corner of the article or click here.

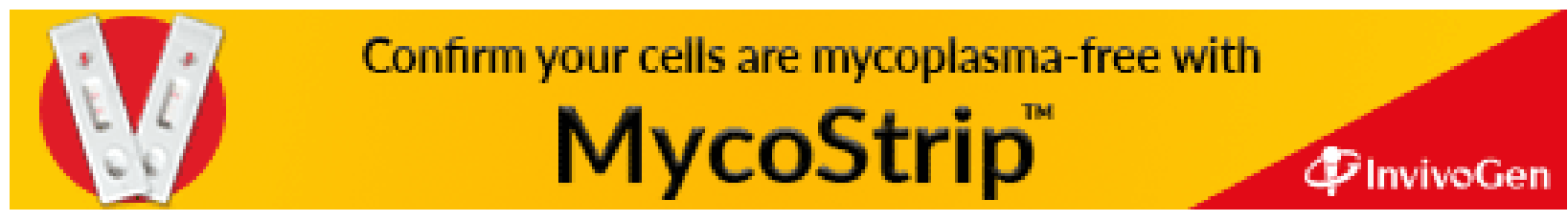

